\title{
Por uma interpretação histórica e liłerária da Educação
}

\author{
Rossana Kess Brito de Souza Pinheiro \\ Universidade Federal do Rio Grande do Norte
}

FIALHO, Lia Machado Fiuza; VASCONCELOS, José Gerardo; SANTANA, José Rogério; VASCONCELOS JÚNIOR, Raimundo Elmo de Paula; RODRIGUES, Rui Martinho (Org.). História, literatura e educação. Fortaleza: Editora da UECE, 2015.

O livro História, Literatura e Educação é resultado do esforço acadêmico de um coletivo de professores e estudantes de graduação, mestrado e doutorado de várias universidades do nordeste brasileiro. Publicado pela Editora da Universidade Estadual do Ceará - UECE, congrega 15 artigos de professores e estudantes dessa universidade, bem como da Universidade Federal do Ceará (UFC), da Universidade Federal do Rio Grande do Norte (UFRN), da Universidade Federal do Recôncavo Baiano (UFRB), da Universidade da Integração Internacional da Lusofonia Afro-brasileira (UNILAB) e Universidade Regional do Cariri (URCA).

O livro em análise abrange temas que vão da seca nordestina, passando pela educação feminina, educação rural, história das instituições educacionais, a clandestinidade estudantil pós-64, até um estudo comparativo entre Freud e Foucault. Ademais, faz reflexões teóricas e metodológicas sobre a pesquisa qualitativa, envolvendo história, educação e literatura. Este livro, pela diversidade temática que apresenta, se propõe a atender às constantes demandas dos pesquisadores que buscam uma interpretação histórica e literária da educação.

A temática da seca é traduzida por muitas vozes em cinco dos quinze artigos, e referenciada em mais quatro deles. Utilizando a literatura como fonte, eles assumem um olhar sobre a temática da seca no Ceará em cem anos entre 1915 e 2015, trazendo a presentidade de um fenômeno endêmico na história dos nordestinos. Os impactos sociais e econômicos que tal fenômeno climático traz para a vida e para acultura do nordeste são interpretados pelo 
viés da literatura, em obras como $\bigcirc$ quinze, de Raquel de Queiroz. A seca e o cotidiano são vistos pelas lentes de cânones da literatura nacional brasileira como Manuel de Oliveira Paiva, Adolfo Caminha e Domingos Olímpio, sobressaindo tipos sociais, anônimos e oligarquias agrárias de classe média numa representação importante à compreensão dos vícios de uma população que, em cem anos, ainda se curva aos benefícios, para não dizer, esmolas que a eterna "indústria da seca" promove em tempos de eleições.

A pesquisa histórica está inserida neste livro em um construto intertextual. Isso significa que os autores aceitam, com base em suas análises, tanto a História como a Literatura como discursos distintos, mas intentam representar as experiências de tempos idos como formas narrativas de representar questões que mobilizam os homens em cada época histórica. Assim, os trechos ficcionais surgem, no texto histórico, como retrato de sua época, e, ao mesmo tempo que espelham, são por ela espelhados. Como destaca Rui Rodrigues, no artigo História, Educação e Literatura, apesar da distinção da linguagem literária e da linguagem histórica, do objeto e objetivos nem sempre se diferenciam; essa relação de afinidade é que permite a contribuição entre elas, incluída, também, a área da Educação. Daí, o cuidado de os autores procedem a uma 252 reflexão sobre análise de dados visuais para pesquisa qualitativa em uma fonte que é tão cara à historiografia, no geral e a historiografia educacional, particularmente: as imagens.

A história das instituições também encontra espaço nesse banquete da diversidade por meio da história da criação do curso de Moda da UFC. A autora Dijane Victor destaca o pioneirismo desse ensino na universidade pública, assim como a importância de tal curso para o nordeste, também contempla as ausências históricas ao evidenciar que, após 20 anos de criação do curso, muitos professores, estudantes e técnicos não sabiam da sua existência, tampouco o que lá era ensinado. A moda aparece nas conclusões da autora como balizador social que pode muito bem expressar a identidade histórica do lugar. Todo o livro remete a isso: identidade e consciência histórica.

Inserindo-se no contexto da discussão proposta pelo livro, a temática da educação é trazida de modo diretivo em sete artigos e, de modo mais transversal, em dois deles, como na discussão sobre clandestinidade a partir da trajetória do estudante Jorge Romeu Paiva no pós-1964. Uma educação pela tradição é evidenciada na pesquisa de Josier Ferreira da Silva sobre as tradições agrárias da Festa de Santo Antônio, no município de Barbalha, região 
do Cariri cearense. A seca reaparece, nesse cenário, ao trazer uma educação rural que clama por progresso no meio rural em vozes sonantes entre 1930 e 1950, com base no esforço teórico da professora Fátima Leitão de Araújo.

Igualmente a ela, outros pesquisadores em educação oportunizam o conhecimento de outras realidades históricas numa linha curva que percorre quase 800 quilômetros de estradas desde Quixadá, Juazeiro do Norte e Barbalha, no Estado do Ceará, até encontrar a negritude de Anna das Dores, na cidade de Caicó, no Estado do Rio Grande do Norte. O artigo A educação primária de uma estudante negra (Caicó, Rio Grande do Norte, 1923-1928), da autora Maria Marta de Araújo traz o curso formativo dessa neta de escravos - Anna das Dores - a partir do seu próprio testemunho e do relato da sua filha, Ana Zélia Maria Moreira, cotejado pela legislação da época. Suas análises e interpretações conduzem à conclusão sobre a existência de uma emergência naqueles anos de 1920, no interior do Brasil: uma educação primária (e feminina!) como direito de todos e voltado às distintas classes sociais.

O sertão traz surpresas. E a História das Mulheres também. Como a história da Irmã Maria Montenegro a partir do artigo Educadora irmã Maria Montenegro: Mulher Luz (1923-2008), da autora Lia Fialho. Uma menina que deixou o interior do Ceará e se tornou figura emblemática para a Educação Básica do Estado do Ceará, entre 1969, quando assumiv o Colégio Imaculada Conceição, em Fortaleza em 2008, ano do seu falecimento.

Essa "linha curva" aqui referida abarca um universo bem próprio da maioria dos artigos do livro: o Brasil de dentro. Um esforço por sertaniar verbo ainda em processo de reconhecimento - tem sido feito na última década a partir dos estudos pós-coloniais ou do movimento decolonial IMIGNOLO, 2008) permitindo repensar uma epistemologia branca, burguesa e eurocêntrica. Talvez se possa pensar que se está, a partir dessa linha geográfica escolhida pelos pesquisadores deste livro, afirmando um movimento de sertanejar (decolonial, portanto!) admitindo que não haja uma história única.

Sertania é uma matriz educacional que tem servido de base epistemológica para estudar o Brasil de dentro ou o Brasil "real" do professor João Batista de Albuquerque Figueiredo ao destacar a cultura sertaneja nordestina no seu cotidiano e na literatura que versa sobre esse lugar que educa, mas que se faz, em sua linguagem literária e histórica, não, apenas, a História 
do Nordeste, História das Mulheres ou História da Educação, mas também a História do Brasil e dos brasileiros.

As relações que organizam as três áreas em foco tematizam e problematizam um Brasil de dentro que, embora muito se diga, tem muito a dizer a nós e à nossa História pelos vieses da Educação e da Literatura. E esse é o propósito do livro. Um propósito que, em seus 15 ensaios, artigos ou relatórios de pesquisa, conduzem nosso olhar pelas sendas desse Brasil-Nordeste e sobre suas práticas educativas e literárias em um passeio histórico entre os anos de 1915 e 2008 desse Ser-Tão nordestino.

\title{
Referência
}

MIGNOLO, Walter. Desobediência epistêmica: a opção descolonial e o significado de identidade em políica. Cadernos de Letras da UFF, Rio de Janeiro, n. 34. p. 287-324, jul-dez. 2008.

\author{
Profa. Dra. Rossana Kess Brito de Souza Pinheiro \\ Universidade Federal do Rio Grande do Norte \\ Departamento de Fundamentos e Políticas da Educação \\ Grupo de Pesquisa Sertania, Educação e Práticas Culturais \\ E-mail | rossanakpinheiro@hotmail.comom
}

Recebido 2 maio 2017 Aceito 30 maio 2017 